\title{
The yoked control in instrumental avoidance conditioning: An empirical and methodological analysis
}

\author{
A. A. BUERGER \\ Department of Community Health Science, Michigan State University, East Lansing, Michigan 48824 \\ E. M. EISENSTEIN \\ Department of Biophysics, Michigan State University, East Lansing, Michigan 48824 \\ and \\ R. L. REEP \\ Department of Anatomy, School of Medicine, University of Michigan, Ann Arbor, Michigan 48709
}

\begin{abstract}
Analysis of the cockroach experimental data clearly indicates that several of the transition probabilities "forbidden" in the theoretical analysis of Church et al. do in fact occur, and furthermore, that there is a distinct temporal trend to these transition probabilities suggesting that the behavior of headless cockroaches changes as a function of training. Although these changes in transition probabilities are not definite proof that learning has occurred, they are consistent with the concept that learning has occurred in the headless cockroach using a yoked control in instrumental learning.
\end{abstract}

Using the asymptotic probabilities of a discrete Markov process as a model for instrumental conditioning when a yoked control is selected, Church and others (Church, 1964; Church \& Getty, 1972; Church \& Lerner, 1976) have shown that it is possible that "individual differences in reactivity to an event, or even moment-to-moment differences in reactivity of a single subject to an event can lead to performance differences between the experimental animal and its yoked control"' (Church \& Lerner, 1976, p. 440), and thus lead to the possibly erroneous conclusion that learning may have occurred.

In this theoretical approach, at least two empirically incorrect assumptions were made. The first assumption was that there was no change with the time in the discrete transition matrix used to develop the asymptotic probabilities; thus, Church and his co-workers assume constant asymptotic values which do not change with training. The second assumption was that certain transition probabilities were zero; that is, the transitions between certain behavioral states never occurred (Church \& Lerner, 1976). We term such transitions, to which Church and Lerner assigned a value of zero, "forbidden" (see Table 1, which is analogous to Table B on p. 442 in Church \& Lerner, 1976). We recognize that alternative transition matrices could be developed in which these "for-

We wish to thank Michael H. Branson, Professor, Department of Community Health Science, Michigan State University, for his help with this manuscript. bidden" probabilities would not be assigned a value of zero. However, it would be difficult or impossible to use revised transition matrices of this type to model the empirical evidence presented below, because the entries in the probability matrix would have to change with time; in other words, some allowance for the temporal evolution of the matrix would be required.

Using the data of Reep, Eisenstein, and Tweedle (1980), we analyzed the polygraph records of instrumental avoidance training of 10 sequential pairs of

Table 1

Matrix of Transition Probabilities According to the Model of Church and Lerner (1976)

\begin{tabular}{|c|c|c|c|c|}
\hline \multirow[b]{2}{*}{$t$} & \multicolumn{4}{|c|}{$t+1$} \\
\hline & $S_{1}$ & $\mathrm{~S}_{2}$ & $\mathrm{~S}_{3}$ & $\mathrm{~S}_{4}$ \\
\hline $\mathrm{S}_{1}$ & $\mathrm{p}^{2}$ & pq (1) & $\mathrm{pq}(2)$ & $q^{2}$ \\
\hline $\mathrm{S}_{2}$ & $0^{*}(5)$ & $\mathrm{p}$ & $0^{*}$ & q (3) \\
\hline $\mathrm{S}_{3}$ & 1 (4) & $0^{*}$ & 0 & $0^{*}(6)$ \\
\hline $\mathrm{S}_{4}$ & 1 & $0 *(7)$ & $0^{*}(8)$ & 0 \\
\hline
\end{tabular}

Note-These transition probabilities are used to generate the asymptotic probabilities defining the theoretical probability of leg insertion or withdrawal (see Church \& Lerner, 1976, for details). $S_{1}, S_{2}, S_{3}$, and $S_{4}$ are the behavioral states defined in Table 2. Numerals 14 are used as symbols for the allowed transition probabilities; numerals 5.8 are used as symbols for the forbidden transition probabilities. $\quad$ *The six transitions that can occur when a continuous method of Markov chain analysis is used and that are assigned zero probability in the model of Church and Lerner (1976); note that four of these "forbidden" iransitions clearly occur (Table 2 and Figure 1B) and the other two transitions may occur occasionally (Table 2). 
positional $(\mathbf{P}$, or experimental) and random $(\mathbf{R}$, or control) cockroaches (see Horridge, 1962, for terminology); there are clear temporal trends to these transition probabilities, and some of the forbidden transitions definitely occur. In our empirical analysis, we assumed a Markov process which is continuous in time rather than discrete, as Church and Lerner did, because this assumption is more appropriate when one is dealing with experimental data in which there is a clear temporal trend due to the fact that one records all the transitions which actually occur rather than only a subsample of them. Because we assumed a continuous process, all interstate transitions were counted; if a discrete process had been assumed, only transitions occurring between the beginning and end of an arbitrary time interval would have been counted. Furthermore, if one assumes a discrete process, then transitions from any given state to that same state may occur, whereas, in a continuous empirical analysis, transitions from any given state to that same state cannot occur. Hence, the $S_{1}$ to $S_{1}, S_{2}$ to $S_{2}, S_{3}$ to $S_{3}$, and $S_{4}$ to $S_{4}$ transitions never occur in our data presented in Table 2, whereas they are possible in the model of Church and others as summarized in Table 1. Because of our "continuous" as opposed to "discrete" approach, there were six theoretically for-
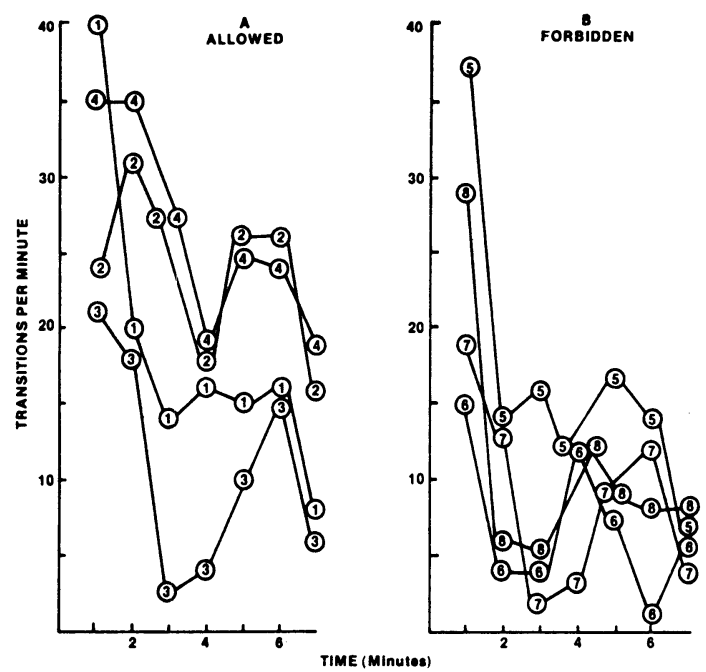

Figure 1. Plot of the number of transitions per minute for the first $7 \mathrm{~min}$ of instrumental avoidance leg-lift training in the headless cockroach. The data were gathered from 10 sequentially trained positional (P) and random (R) pairs. In all cases, the number and, therefore, rate of transition declines with time. Figure 1A shows the transitions "allowed" in the Markov model proposed by Church and others to explain apparent instrumental avoidance learning when a yoked control is used. Figure 1B shows transitions "forbidden" by the Church model. The transitions plotted above are labeled 1 through 8, as shown in Table 1 . According to the model proposed by Church and others, there should be no decline in transition rate with time, as demonstrated in Figures $1 \mathrm{~A}$ and 1B, and there should be no transitions of the type shown in Figure $1 B$.

Table 2

The Transition Matrix Generated by an Analysis of the First 7 Min of Training of 10 Sequential Pairs of Cockroaches in an Instrumental Avoidance Conditioning Paradigm

\begin{tabular}{|c|c|c|c|c|c|c|c|c|c|c|c|c|c|c|c|c|c|c|c|c|c|c|c|c|c|c|c|c|c|}
\hline & & \multicolumn{28}{|c|}{$t+\Delta$} \\
\hline & \multirow[b]{3}{*}{$\mathrm{N}$} & \multicolumn{7}{|c|}{$\begin{array}{l}S_{1} \\
{[P(E) U p(O u t) /} \\
R(C) U p(O u t)]\end{array}$} & \multicolumn{7}{|c|}{$\begin{array}{c}\mathrm{S}_{2} \\
{[\mathrm{P}(\mathrm{E}) \mathrm{Up}(\mathrm{Out}) /} \\
\mathrm{R}(\mathrm{C}) \text { Down (In)] }\end{array}$} & \multicolumn{7}{|c|}{$\begin{array}{c}\mathrm{S}_{3} \\
{[\mathrm{P}(\mathrm{E}) \text { Down (In)/ }} \\
\mathrm{R}(\mathrm{C}) \mathrm{Up} \text { (Out)] }\end{array}$} & \multicolumn{7}{|c|}{$\begin{array}{l}\mathrm{S}_{4} \\
{[\mathrm{P}(\mathrm{E}) \text { Down (In)/ }} \\
\mathrm{R}(\mathrm{C}) \text { Down (In)] }\end{array}$} \\
\hline & & \multicolumn{7}{|c|}{ Minute } & \multicolumn{7}{|c|}{ Minute } & \multicolumn{7}{|c|}{ Minute } & \multicolumn{7}{|c|}{ Minute } \\
\hline & & 1 & 2 & 3 & 4 & 5 & 6 & 7 & 1 & 2 & 3 & 4 & 5 & 6 & 7 & 1 & 2 & 3 & 4 & 5 & 6 & 7 & 1 & 2 & 3 & 4 & 5 & 6 & 7 \\
\hline$S_{1}$ & $\begin{array}{l}\text { T } \\
\mathbf{A}\end{array}$ & & & & & & & & $\begin{array}{r}40 \\
8\end{array}$ & $\begin{array}{r}20 \\
8\end{array}$ & $\begin{array}{r}14 \\
7\end{array}$ & $\begin{array}{r}16 \\
7\end{array}$ & $\begin{array}{r}15 \\
5\end{array}$ & $\begin{array}{r}16 \\
6\end{array}$ & $\begin{array}{l}8 \\
7\end{array}$ & $\begin{array}{r}24 \\
6\end{array}$ & $\begin{array}{r}31 \\
7\end{array}$ & $\begin{array}{r}27 \\
7\end{array}$ & $\begin{array}{r}18 \\
6\end{array}$ & $\begin{array}{r}26 \\
4\end{array}$ & $\begin{array}{r}26 \\
5\end{array}$ & $\begin{array}{r}16 \\
5\end{array}$ & $\begin{array}{l}3 \\
2\end{array}$ & & & & $\begin{array}{l}1 \\
1\end{array}$ & $\begin{array}{l}1 \\
1\end{array}$ & $\begin{array}{l}1 \\
1\end{array}$ \\
\hline $\mathrm{S}_{2}$ & $\begin{array}{l}\mathbf{T} \\
\mathbf{A}\end{array}$ & $\begin{array}{r}37 \\
7\end{array}$ & $\begin{array}{r}14 \\
8\end{array}$ & $\begin{array}{r}16 \\
7\end{array}$ & $\begin{array}{r}12 \\
6\end{array}$ & $\begin{array}{r}17 \\
6\end{array}$ & $\begin{array}{r}14 \\
7\end{array}$ & $\begin{array}{l}7 \\
5\end{array}$ & & & & & & & & $\begin{array}{l}1 \\
1\end{array}$ & $\begin{array}{l}2 \\
1\end{array}$ & & $\begin{array}{l}1 \\
1\end{array}$ & $\begin{array}{l}1 \\
1\end{array}$ & & & $\begin{array}{r}21 \\
6\end{array}$ & $\begin{array}{r}18 \\
4\end{array}$ & $\begin{array}{l}3 \\
3\end{array}$ & $\begin{array}{l}4 \\
3\end{array}$ & $\begin{array}{r}10 \\
3\end{array}$ & $\begin{array}{r}15 \\
6\end{array}$ & $\begin{array}{l}6 \\
4\end{array}$ \\
\hline $\mathrm{S}_{3}$ & $\begin{array}{l}\mathbf{T} \\
\mathbf{A}\end{array}$ & $\begin{array}{r}35 \\
8\end{array}$ & $\begin{array}{r}35 \\
8\end{array}$ & $\begin{array}{r}27 \\
6\end{array}$ & $\begin{array}{r}19 \\
5\end{array}$ & $\begin{array}{r}25 \\
3\end{array}$ & $\begin{array}{r}24 \\
5\end{array}$ & $\begin{array}{r}19 \\
6\end{array}$ & & $\begin{array}{l}4 \\
3\end{array}$ & $\begin{array}{l}3 \\
1\end{array}$ & & $\begin{array}{l}4 \\
4\end{array}$ & $\begin{array}{l}3 \\
2\end{array}$ & & & & & & & & & $\begin{array}{c}15 \\
6\end{array}$ & $\begin{array}{l}4 \\
2\end{array}$ & $\begin{array}{l}4 \\
1\end{array}$ & $\begin{array}{r}12 \\
2\end{array}$ & $\begin{array}{l}8 \\
1\end{array}$ & $\begin{array}{l}1 \\
1\end{array}$ & $\begin{array}{l}6 \\
1\end{array}$ \\
\hline$S_{4}$ & $\begin{array}{l}\text { T } \\
\text { A } \\
\end{array}$ & $\begin{array}{l}5 \\
4 \\
\end{array}$ & $\begin{array}{l}2 \\
2 \\
\end{array}$ & & & $\begin{array}{l}1 \\
1\end{array}$ & & & $\begin{array}{r}19 \\
7\end{array}$ & $\begin{array}{r}13 \\
3\end{array}$ & $\begin{array}{l}2 \\
2 \\
\end{array}$ & $\begin{array}{l}3 \\
2 \\
\end{array}$ & $\begin{array}{l}9 \\
3 \\
\end{array}$ & $\begin{array}{r}12 \\
6 \\
\end{array}$ & $\begin{array}{l}4 \\
2 \\
\end{array}$ & $\begin{array}{r}29 \\
8\end{array}$ & $\begin{array}{l}6 \\
2 \\
\end{array}$ & $\begin{array}{l}5 \\
1 \\
\end{array}$ & $\begin{array}{r}12 \\
3 \\
\end{array}$ & $\begin{array}{l}9 \\
2\end{array}$ & $\begin{array}{l}8 \\
3\end{array}$ & $\begin{array}{l}8 \\
2\end{array}$ & & & & & & & \\
\hline
\end{tabular}

Note $-S_{1}-S_{2}$ are behavioral states identical to those defined by Church and Lerner (1976); they are a function of the relative leg position of $P$ (positional) and $R$ (random) animals during instrumental avoidance conditioning with a yoked control. For example, in $S_{2}$ the leg of the $P$ (or experimental, E) animal would be flexed or up and out of the saline through which shock was delivered, and the leg of the $R$ (or control, $C$ ) animal would be extended or down and in the saline. The table is composed of 16 cells, each of which represents a transition from the behavioral states represented by the rows at time t to the behavioral state represented by the columns at time $t+\Delta$ For example, the cell at the intersection of the column labeled $S_{2}$ and the row labeled $S_{1}$ represents a transition from behavioral state $S_{1}$ (in which both $P$ and $R$ are flexed, or out) to behavioral state $S_{2}$ (in which $P$ remains flexed, or out, and $R$ is extended, or in). Within each cell, there are seven subcells, representing the first 7 min of training. The four cells on the diagonal from upper left to lower right are empty because they cannot occur when a continuous method of Markov chain analysis is used. For the $N$ column, $T=$ the number of transitions of the type indicated that occurred in the minute indicated; $A=$ the number of animals that made that type of transition in the minute indicated. Note the decline in transition rate from Minute 1 to Minute 7 ; these rates of transition are plotted in Figure 1. Note that four of the six transitions that are assigned zero probabilities in the model of Church and Lerner clearly occur (see Table 1) and that the remaining two transitions probably also occur. Also note the decline in transition rate from Minute 1 to Minute 7; these rates of transition are plotted in Figure 1A. Furthermore, note that four of the six cells that are assigned zero probabilities in the Markov model of Church and Lerner clearly occur; these are plotted in Figure 1B. 
bidden transitions; these are marked by asterisks in Table 1. Of these six, four clearly occur (see Figure 1 and Table 2 ) and the remaining two may occur occasionally (see Table 2).

In summary, our analysis of the cockroach experimental data clearly indicates that (1) several of the transition probabilities "forbidden" in the theoretical analysis of Church et al. do in fact occur (Table 2), and (2) there is a distinct temporal trend to these transition probabilities suggesting that the behavior of headless cockroaches changes as a function of training (Figure 1).

Although these changes in transition probabilities are not definitive proof that learning has occurred, they are entirely consistent with the concept that learning has occurred in the headless cockroach using a yoked control in instrumental avoidance conditioning.

\section{REFERENCES}

Church, R. M. Systematic effect of random error in the yoked control design. Psychological Bulletin, 1964, 62, 122-131.

Church, R. M., \& GetTy, D. J. Some consequences of the reaction to an aversive event. Psychological Bulletin, 1972, 78, 21-27.

Church, R. M., \& Lerner, N. D. Does the headless roach learn to avoid? Physiological Psychology, 1976, 4, 439-442.

Horridge, G. A. Learning of leg position by the central nerve cord in headless insects. Proceedings of the Royal Society, 1962, 157B, 33-52.

Reep, R. L., Eisenstein, E. M., \& Tweedle, C. D. Neuronal pathways involved in transfer of information related to leg position learning in the cockroach, $P$. Americana. Physiology \& Behavior, 1980, 00, 501-513. 